\title{
SSynthesis
}

International Scientific Conference of IT and Business-Related Research

\section{SPANISH FOR SPECIFIC PURPOSES: TOURISM}

\author{
ŠPANSKI KAO JEZIK STRUKE: TURIZAM
}

\author{
Marina Milovanović, Aleksandra Gagić, Maja Veljković Michos, Ana Petrović \\ Singidunum University, 32 Danijelova St., 11000 Belgrade, Serbia
}

\begin{abstract}
:
A modern way of living and doing business has a considerable impact on the rapid exchange of information and data, especially in the domain of business. Therefore, computer literacy and knowledge of foreign languages are nowadays considered mandatory for pursuing a successful career in the chosen field. Additionally, it can be said that modern business is characterized by multilingualism and HR expertise within a specific area, and a growing demand for learning LSP.

Spanish holds the second place as one of the most widely distributed languages and it plays an important role in everyday communication, and is considered an indispensable factor in the contemporary business world. In addition, some recent studies have drawn attention to the importance and growing demand for learning Spanish for specific purposes. The aim of this paper is to present the methods of preparation and use of didactic material for learning Spanish as LSP, with special emphasis on the tourism field. The authors shall attempt to draw attention to the issues and challenges the teaching staff faces, mostly due to not being sufficiently conversant with technical terminology and LSP, as well as to propose the ways to overcome such obstacles and provide the examples of best practice and relevant case studies.
\end{abstract}

\section{Key words:}

foreign languages, LSP, Spanish language, teacher, tourism field.

\section{INTRODUCTION}

Due to the extensive use of computers and other electronic devices, a modern man has been forced to adapt to an incessant and hectic pace of life. Such lifestyle has also had a considerable bearing on the overall communication and the way of doing business. Nowadays, people living in different parts of the world work together and cooperate, communicate, exchange ideas and human resources, adopt new knowledge and skills. In such an environment, a new generations of experts are produced, who start with their professional development and seek internships and employment while still at the university. A university degree is no longer sufficient for pursuing a desirable career and making progress in the business world. Competitive skills of candidates looking for employment within a certain field can be observed through several main parameters: knowledge in the given field or profession (which implies attending certain courses, seminars, conferences, doing internships, voluntary work etc., besides gaining a university degree), computer literacy, knowledge of English and some other foreign language.

Nowadays, most people need to possess considerable professional knowledge and skills besides general knowledge, and

\section{Apstrakt:}

Savremen način života i poslovanja u velikoj meri utiče na brzu razmenu informacija i podataka, naročito u domenu poslovanja, te se stoga poznavanje rada na računaru i aktivno učenje stranih jezika smatra preduslovom za uspešnu karijeru. Može se reći da savremeno poslovanje karakterišu višejezičnost i stručnost ljudskih resursa u određenoj oblasti, što utiče na povećanu potrebu za učenjem jezika struke.

Španski jezik je drugi najzastupljeniji jezik i igra veliku ulogu u svakodnevnoj komunikaciji i savremenom poslovanju. Nedavno sprovedena istraživanja ukazuju na sve veći značaj i potrebu za učenjem španskog jezika kao jezika struke.

Cilj ovog rada jeste da predstavi način pripreme i upotrebe didaktičkog materijala za učenje španskog jezika kao jezika struke, sa posebnim akcentom na španski jezik u oblasti turizma. Autori će pokušati da ukažu na probleme i izazove sa kojima se susreće nastavni kadar, pre svega usled nedovoljnog poznavanja stručne terminologije i stranog jezika struke, kao i da ukažu na načine na koje je moguće prevazići te prepreke, oslanjajući se na primere dobre prakse i studije slučaja.

\section{Ključne reči:}

strani jezici, jezik struke, španski jezik, nastavnik, turizam.

should aim to become experts in their respective fields. Therefore, it is of vital importance for the current and upcoming generations to devote special attention to learning and mastering foreign language/languages. However, the emphasis is no longer on gaining general language skills, as was the case with our professors and senior colleagues, but on learning languages for specific purposes (LSP) that would enable future experts to do business successfully and foster international cooperation.

English is still the most widely used language and certainly the most important language in the business world and communication. According to the BEI (Business English Index), over one third of the surveyed countries have earned a score of 4.00, which indicates elementary level of Business English, thus implying capability to manage simple phone conversations and communicate basic business information. As regards Spain, which is one of the most developed tourism countries, its average score was 4.18 (Business English Index, Internet). Therefore, the purpose of this paper is to show why it is important to learn Spanish for tourism purposes, and how some faculties, except for the Faculty of Philology, place an emphasis on learning Spanish as LSP. 


\subsection{METHODOLOGY}

The paper shall present some relevant research findings showing whether the students are and to what extent motivated to learn Spanish as LSP. This work is conceptually divied into two parts; the first one contains the results of research conducted in Europe and around the world, whereas the second part presents the analysis of statistical data and results of the survey carried out at the Faculty of Toursim and Hospitality Management within Singidunum University.

The analysis and synthesis of data, statistical data and the results of the survey conducted, show that the students are very interested in learning Spanih as LSP in the tourism sector, but that it is necessary to work on improving the language level of future experts in the tourism field.

\section{SPANISH AS LSP: TOURISM}

The special edition of the Eurobarometer published by the European Commission examines the importance and draws attention to the necessity of learning and actively using foreign languages, mostly on the territory of the EU (Special Eurobarometar, 2014). It puts an emphasis on the three main goals of the analysis: a) a long-term goal for all citizens of the EU should be to actively use two foreign languages besides their mother tongue $\mathrm{b}$ ) life-long learning of foreign languages that would be initiated in the early childhood and c) education.

The future multilingual European should be:

1. young

2. educated

3. should have parents living abroad, i.e. in some other country rather than the one he/she resides in

4. a student or a manager holding a position that requires knowledge of foreign languages

5. motivated to learn (Special Eurobarometer, Internet).

Besides numerous encouraging results of the Eurobarometer research, there are many not so favourable data for the countries such as Spain and Italy. Namely, only $17 \%$ of the entire population of Spain and $16 \%$ of the entire population of Italy speaks some foreign language. In Europe, the following languages are most widely spoken as second foreign languages (SFL), immediately after English: German, French, Spanish, and Russian. Around 6\% of the entire EU population speaks Spanish as a second foreign language.

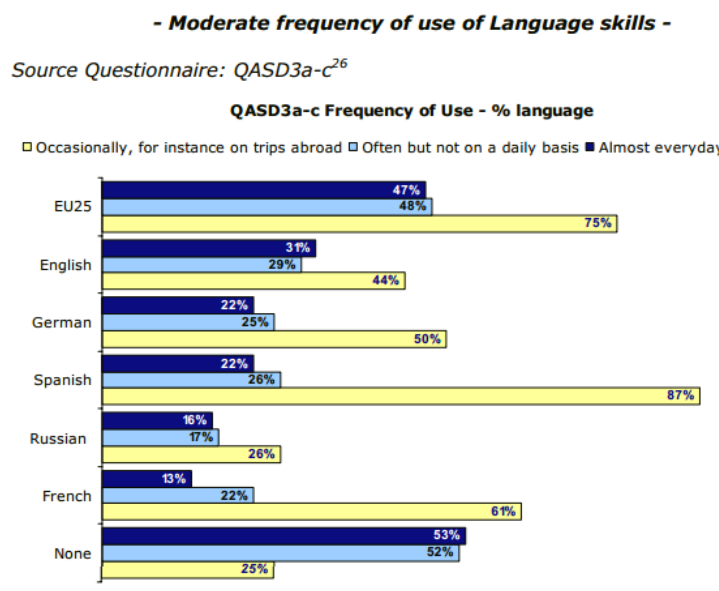

Figure 1. Frequency of use of foreign languages

Source: Special Eurobarometer
Even though Spanish as a second foreign language in Europe is not most widely used according to the statistics, the situation is quite different when it comes to travelling. Namely, Spanish is the most frequently used foreign language for travelling purposes, spoken by more than $87 \%$ of people. This is mostly due to the fact that Spain is among the most developed tourism countries, both in Europe and worldwide. According to its tourism revenue, it holds the second position in the world.

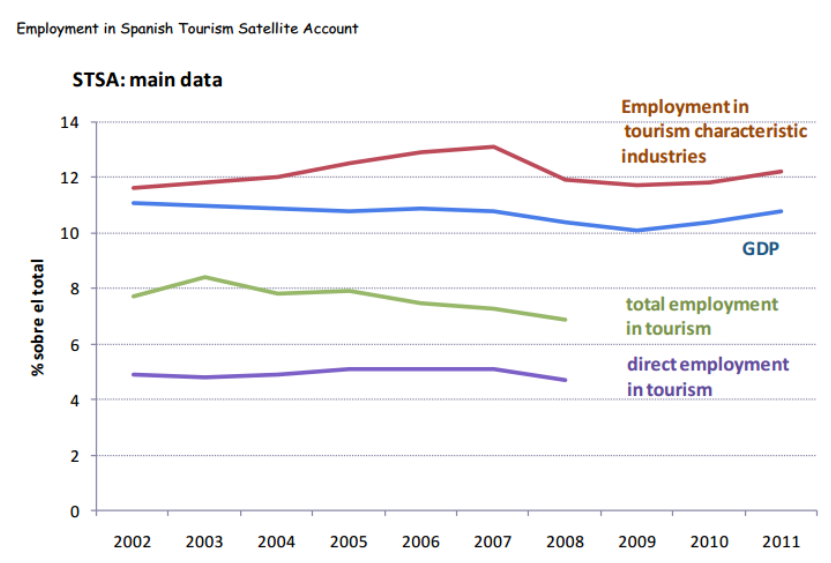

Figure 2. Employment according to STSA

Source: Spanish Tourism Satellie Account

The following conclusions can be drawn based on the previously presented data:

1. Spain is a very developed tourism country whose tourism development considerably affects its overall economy.

2. Tourism development in Spain has an impact on the employment rate.

3. Spanish people do not have a high level of English for business purposes.

4. A small percentage of Spanish population speaks some foreign language.

All this indicates the necessity to study Spanish as LSP, primarily in the tourism field (Sánchez Lobato \& Santos Gargallo, 2004).

Some studies reveal that students attending the faculties other than the Faculties of Philology have recognized the importance of learning a foreign language as LSP, but they are often of the opinion that English is sufficient and that second foreign language, as LSP, is not so important for their future careers (Božinović \& Sindik, 2013).

As can be concluded based on the modern didactic material, the emphasis is put on introducing Spanish as LSP from the elementary level (A1). Long time ago, business language was introduced at level B1. However, in order to keep pace with the needs of the modern market concerning the knowledge of Spanish as LSP, considerable number of business course books has been designed starting from the level A1.

\section{THE ROLE OF A TEACHER IN THE PROCESS OF LEARNING SPANISH AS LSP: TOURISM}

A series of innovations occured both in the teaching process in general, as well as in foreign language teaching process, and this paper shall mention the two very important innovations in the domain of foreign language teaching: 
1. The use of ICT in the teaching process. In a situation when the teachers have to work with students who are digital natives, it is mandatory for them to be conversant with and actively use ICT in the teaching process (Radić Branisavljević \& Milovanović, 2014).

2. Foreign language as LSP. At the universities in Serbia, Faculties of Philology, general language is being taught, and thus a great majority of professors, in particular those who graduated several decades ago, have not had the opportunity to study or learn LSP. Today, we are facing with a growing need for learning foreign languages for specific purposes (LSP).

The first question that arises is whether the teacher who starts teaching some foreign language as LSP, needs to be conversant with the given profession/field (Gómez de Enterría, 2008). The second question that should be taken into consideration is whether or not being conversant with the certain field represents an advantage or a flaw.

Being familiar with a certain field when teaching a foreign language as LSP can be an advantage, but should not be the prerequisite for getting the desired employment. The teacher who is dealing with such technical terms for the first time, can obtain necesssary information through interaction with students. Thus, the emphasis is placed on the student as he/she is the one who helps and explains certain issues and concepts to the teacher and becomes a more active participant in the learning process (Vučo et al., 2009). This certainly contributes to creating a partner-like relationship between the student and the teacher. Therefore, not being conversant with some field and technical terms is neither a flaw nor a hendicap of the teacher, but rather an advantage. In addition, in such an environment, the sudents can take an active part in building the glossary for the given profession or field, which would make them the main participants in the process, while the teachers will coordinate such activities (Sánchez Lobato \& Santos Gargallo, 2004).

Despite lacking knowledge of Spanish as LSP in the tourism field, the teacher is somewhere expected to gradually work on improving and expanding his/her knowledge and vocabulary intended for communication in the tourism sector. The teachers and universities in Serbia mostly cooperate with the Cervantes Institute, as there they can find additional material that could enable them to introduce appropriate practical exercises for teaching Spanish as LSP. In addition, the Institute organizes numerous courses, worshops and seminars for those who teach Spanish as LSP. However, it should be noted that no such or similar courses have been organized recently.

\section{SURVEY CONDUCTED AT THE FACULTY OF TOURISM AND HOSPITALITY MANAGEMENT - SINGIDUNUM UNIVERSITY}

Years of learning Spanish as a Second Foreign Language:

- 4 years

Language Level upon graduation:

- B1

Course book:

- Pasaporte A1+A2 (Cerrolaza et al., 2009)

- Pasaporte B1 (Cerrolaza et al., 2009)

Available audio/visual resourses and materials:

- projector, computer, Internet, electronic classrooms

\subsection{ANALYSIS OF NEEDS}

According to recent research and practical experience, it can be concluded that there are three main reasons that trigger students, in particular the students of the Faculty of Toursim and Hospitality Management, to study Spanish:

1. they like Spanish

2. they wish to work in the tourism sector

3. they want to connect pleasure and business- travel to Spain and find employment

Having in mind the above-stated, it is possible to design curricula that would meet some basic needs of students, and that would include technical terminology and the ways of doing business communication in Spanish as LSP.

Those who are part of the modern business world communicate on a daily baisis, exchange information and knowledge, make phone calls, conduct meetings using sometimes simple, and sometimes complex vocabulary or a mixture of both, and grammatical constructions. Also, there are special expressions and phrases used in the business world, both in written and oral communication. The goal of the teacher would be to help the students to master certain grammar-lexical units, but also to place them in real- lfe situations using ICT where they could apply the acquired knowledge (Warrschauer \& Meskill, 2000).

\subsection{CURRICULA ACCORDING TO LANGUAGE LEVEL}

Coursebook Pasaporte is treated as a general coursebook, and it contains the so-called ámbito profesional (professional part) within each module, which deals with different professions and business situations that foster communication. Upon completion of a certain language level, students are expected to do the following:

\begin{tabular}{|c|c|c|c|}
\hline & Reading & Writing & Listening/Speaking \\
\hline A1 & $\begin{array}{l}\text { Students } \\
\text { should become } \\
\text { conversant } \\
\text { with the basics } \\
\text { of the Spanish } \\
\text { language and } \\
\text { Hispanic cul- } \\
\text { ture, and should } \\
\text { be able to read } \\
\text { and understand } \\
\text { shorter texts }\end{array}$ & $\begin{array}{l}\text { Students } \\
\text { should be able } \\
\text { to write short } \\
\text { notes and } \\
\text { descriptions } \\
\text { using simple } \\
\text { constructions }\end{array}$ & $\begin{array}{l}\text { Students should be } \\
\text { able to understand } \\
\text { short dialogues; ba- } \\
\text { sic communication } \\
\text { and exchange of } \\
\text { information using } \\
\text { simple language } \\
\text { constructions and } \\
\text { vocabulary }\end{array}$ \\
\hline A2 & $\begin{array}{l}\text { Students should } \\
\text { be able to read } \\
\text { and understand } \\
\text { complex narra- } \\
\text { tive and descrip- } \\
\text { tive texts }\end{array}$ & $\begin{array}{l}\text { Students } \\
\text { should be able } \\
\text { to write essays } \\
\text { of descriptive } \\
\text { and narrative } \\
\text { form with an } \\
\text { emphasis on } \\
\text { past tenses }\end{array}$ & $\begin{array}{l}\text { Students should be } \\
\text { able to manage in } \\
\text { complex commu- } \\
\text { nication situations } \\
\text { and link the past } \\
\text { and the present }\end{array}$ \\
\hline B1 & $\begin{array}{l}\text { Introduction } \\
\text { to professional } \\
\text { terminology/ } \\
\text { technical terms }\end{array}$ & $\begin{array}{l}\text { Students } \\
\text { should } \\
\text { master and } \\
\text { use technical } \\
\text { terminology }\end{array}$ & $\begin{array}{l}\text { Students should be } \\
\text { able to manage in } \\
\text { daily communica- } \\
\text { tion as well as in } \\
\text { business environ- } \\
\text { ment }\end{array}$ \\
\hline
\end{tabular}

Table 1. Development of Laguage Skills using coursebook Pasaporte (own source) 


\subsection{INTRODUCTION TO PROFESSIONAL TERMINOLOGY}

Coursebook and workbook Pasaporte A1+A2 i B1 include the following lessons dealing with the language for business purposes and some business related terminology. Below are given the examples of how certain general business fields are adjusted to the needs of students who are learning Spanish at the Faculty of Tourism and Hospitality Management.

\section{$\mathrm{A} 1+\mathrm{A} 2\left(1^{\text {st }}\right.$ and $2^{\text {nd }}$ year of learning $)$}

\begin{tabular}{|c|c|}
\hline Module1 & $\begin{array}{l}\text { Ámbito profesional: Eres capaz de confeccionar } \\
\text { tu propia tarjeta de visita para presentarte formal- } \\
\text { mente en español.La profesión u ocupación. } \\
\text { In this lesson we deal with the topic of professions } \\
\text { and employment for the first time }\end{array}$ \\
\hline Module 2 & $\begin{array}{l}\text { Ámbito profesional:eres capaz de describir una } \\
\text { empresa.Presentar formalmente a otras personas. } \\
\text { Introducing oneself in a formal way in the business } \\
\text { environment. The use of demonstrative pronouns } \\
\text { and adjectives. }\end{array}$ \\
\hline Module 3 & $\begin{array}{l}\text { Ámbito profesional: Eres capaz de organizar una } \\
\text { comida de empresa. Manejarse en un restaurante. } \\
\text { The students should be able to manage a business } \\
\text { lunch in a restaurant. They become conversant with } \\
\text { the vocabulary connected to food as well as with } \\
\text { the expressions and phrases used to make orders in } \\
\text { a restaurant or a bar. }\end{array}$ \\
\hline Module 4 & $\begin{array}{l}\text { Ámbito profesional: Eres capaz de ubicarte en un } \\
\text { centro comercial. } \\
\text { Becoming conversant with the terms used for cer- } \\
\text { tain sales and business objects in shopping malls, } \\
\text { adopting expressions and phrases used to ask for or } \\
\text { provide certain information. }\end{array}$ \\
\hline Module 5 & $\begin{array}{l}\text { Ámbito profesional: Eres capaz de quedar con los } \\
\text { conocidos. } \\
\text { Being able to schedule informal meetings, accept } \\
\text { or reject invitations for a meeting, being able to } \\
\text { express planned and desired actions. }\end{array}$ \\
\hline Module 6 & $\begin{array}{l}\text { Ámbito profesional: Eres capaz de hablar por telé- } \\
\text { fono y concertar una cita } \\
\text { Making phone calls and scheduling formal meet- } \\
\text { ings. Adopting relevant vocabulary and expres- } \\
\text { sions. }\end{array}$ \\
\hline Module 7 & $\begin{array}{l}\text { Ámbito profesional: Eres capaz de completar tu } \\
\text { currículum para poder encontrar un trabajo. } \\
\text { Writing a CV. Simulation of a job interview }\end{array}$ \\
\hline Module 8 & $\begin{array}{l}\text { Ámbito profesional: Eres capaz de hacer una recla- } \\
\text { mación. } \\
\text { Writing and expressing complaints, remarks, recla- } \\
\text { mations. }\end{array}$ \\
\hline Module 9 & $\begin{array}{l}\text { Ámbito profesional: Eres capaz de preparar una } \\
\text { entrevista de trabajo. } \\
\text { Being able to present your biography using previ- } \\
\text { ously mastered past tenses }\end{array}$ \\
\hline Module 10 & $\begin{array}{l}\text { Ámbito profesional: Eres capaz de describir el } \\
\text { sistema universitario. } \\
\text { Becoming conversant with the university and } \\
\text { health system in Spain }\end{array}$ \\
\hline
\end{tabular}

Table 2. Spanish as LSP: Tourism (own source)
B1 ( $3^{\text {rd }}$ and $4^{\text {th }}$ year of language learning)

\begin{tabular}{|c|c|}
\hline Module 1 & $\begin{array}{l}\text { Ámbito profesional: los perfiles laborales en Es- } \\
\text { paña. } \\
\text { Special emphasis is placed on professions in the } \\
\text { tourism field. Professional and personal skills rel- } \\
\text { evant for the tourism sector are also discussed. }\end{array}$ \\
\hline Module 2 & $\begin{array}{l}\text { Ámbito profesional: el sistema sanitario español y el } \\
\text { médico de cabecera. } \\
\text { Students are to become conversant with the specif- } \\
\text { ics concerning health care in Spain that could be } \\
\text { useful for those who wish to work in Spain for a } \\
\text { longer or shorther period, as well as for those who } \\
\text { plan to visit Spain as tourists. }\end{array}$ \\
\hline Module 3 & $\begin{array}{l}\text { Ámbito profesional: los españoles y el trabajo. } \\
\text { This section is devoted to the rights and obligations } \\
\text { of employees. Also, there is a suitable lesson to } \\
\text { further elaborate on the topic of those employeed } \\
\text { in the tourism field. }\end{array}$ \\
\hline Module 4 & $\begin{array}{l}\text { Ámbito profesional: biografía de Michelle Bachelet, } \\
\text { presidenta de Chile. } \\
\text { This section deals with the employment issue and } \\
\text { male and female relationship at workplace, as well } \\
\text { as with the position of a woman at workplace. Are } \\
\text { there typical male or female jobs in tourism? }\end{array}$ \\
\hline Module 5 & $\begin{array}{l}\text { Ámbito profesional: la publicidad y los lemas } \\
\text { publicitarios. } \\
\text { Advertising, writing business letters, complaints } \\
\text { within the context of a tourist agency. }\end{array}$ \\
\hline Module 6 & $\begin{array}{l}\text { Ámbito profesional: edificios contemporáneos y } \\
\text { arquitectos españoles con proyección internacional. } \\
\text { Learning about tourism attractions in Spain, im- } \\
\text { portant places to visit, Barcelona, cultural heritage } \\
\text { and other tourism destinations in Spain. }\end{array}$ \\
\hline Module 7 & $\begin{array}{l}\text { Ámbito profesional: la expansión de las nuevas } \\
\text { tecnologías. } \\
\text { Providing a definition of e-marketing in tourist } \\
\text { agencies, online marketing, web sites and advertis- } \\
\text { ing using modern technology. }\end{array}$ \\
\hline Module 8 & $\begin{array}{l}\text { Ámbito profesional: los utensilios de mesa y vo- } \\
\text { cabulario del restaurante. } \\
\text { Ideal topic for developing conversation in a restau- } \\
\text { rant, practising food-related vocabulary etc. }\end{array}$ \\
\hline
\end{tabular}

Table 3. Spanish as LSP: Tourism (own source)

\section{RESEARCH RESULTS}

Research carried out at the Faculty of Tourism and Hospitality Management at Singidunum University examines the importance of learning a foreign language as LSP in the field of tourism and evaluates the awareness of students regarding this issue. There are about 1079 undergraduate students attending this faculty. All students study two foreign languages, with English being obligatory, whereas the second foreign language can be chosen between the following options: French, Spanish, Italian, Russian, German and Chinese.

According to data obtained from the Faculty itself, 513 students have chosen Spanish as their second language, which accounts for $47,5 \%$ of the total number of students (Table 4 ). 


\begin{tabular}{|c|c|c|c|}
\hline $\begin{array}{c}\text { Study } \\
\text { programme }\end{array}$ & Year & $\begin{array}{c}\text { Number of } \\
\text { students }\end{array}$ & $\begin{array}{c}\text { Number of students } \\
\text { learning Spanish }\end{array}$ \\
\hline \multirow{3}{*}{$\begin{array}{c}\text { Tourism and } \\
\text { Hospitality }\end{array}$} & 1 & 224 & 96 \\
\cline { 2 - 4 } & 2 & 209 & 94 \\
\cline { 2 - 4 } & 4 & 294 & 132 \\
\hline \multicolumn{2}{|c|}{} & 352 & 191 \\
\hline
\end{tabular}

Table 4. Number of students learning Spanish in relation to the total number of students.

Source: Singidunum University

\begin{tabular}{|c|c|}
\hline Italian & 28 \\
\hline Spanish & 96 \\
\hline German & 41 \\
\hline Russian & 22 \\
\hline French & 19 \\
\hline Chinese & 4 \\
\hline Unallocated & 11 \\
\hline
\end{tabular}

Table 5: The chosen second foreign language in the school year 2013-2014, $1^{\text {st }}$ year of study.

Source: Singidunum University

As can be observed, the percentage of students who have chosen this language is very high, and such continuing tendency is supported by the data showing that out of the total number of students enrolled in the academic year 2013-2014, 42,9\% of them decided to study Spanish. (Table 5.)

The following results were obtained by means of an anonymous survey carried out at Singidunum University among the students attending Spanish at the Faculty of Tourism and Hospitality Management, Singidunum University (FTHM):

1. $30 \%$ of the respondents said they have chosen Spanish due to its importance in the tourism sector and they believe that the knowledge of Spanish will have a positive bearing on their future career development in the tourism sector.

2. $70 \%$ of the respondents said that they decided to study Spanish because of their affection for Spain, soap operas from the Hispanic speaking area and the music.

3. $23 \%$ of the respondents think that the current course book is excellent, while $18 \%$ consider it quite inadequate.

4. Students assessed the teaching process and introduction to professional terminology with an average score of 4,05 .

\section{CONCLUSION}

The aforementioned research brings us to the conclusion that besides general course books, it is necessary to use other study materials and available resources to enable students to learn a foreign language as LSP. The teacher plays an important role in the overall learning process together with the student.
The teacher contributes to this process as someone who speaks and is conversant with the given language and culture, while the student contributes as someone who is familiar with the technical terms and expressions used in the given field. It is only through their mutual interaction that they can design the teaching units that would lead to adopting technical terminology in the target language and its active use by the student. An adequate use of ICT in the teaching process will certainly enable students to learn the given language in real- life situations and gain relevant business skills (White, 2003).

Spanish as LSP plays an important role in modern business environment and students are very interested in learning it as both general language and LSP. However, research conducted shows that a small percentage of the surveyed students at the Faculty of Tourism and Hospitality Management have chosen Spanish because of its relevance in the tourism sector. Therefore, it is necessary to explain to the young and future experts in the tourism sector why it is important to know and actively use Spanish as LSP. By using the appropriate course books for learning Spanish for specific purposes, and additional material provided by the teacher, it is possible to enable students to gain relevant knowledge and skills in the given field, and participate in the international labour market on an equal footing.

\section{REFERENCES}

Božinović, N., \& Sindik, J. (2013). Language proficiency for careers in tourism and learning second foreign languages. Turizam, 17(3), pp. 121-130.

Business English Index. (n.d.). Retrieved June 6, 2014, from http:// www.globalenglish.com/business english index

Cerrolaza Aragón, M., Cerrolaza Gili, Ó., \& Llovet Barquero, B. (2009). Pasaporte B1. Madrid: Edelsa.

Cerrolaza Aragón, M, Cerrolaza Gili, Ó., Llovet Barquero, B. (2009). Pasaporte Compilado A1+A2. Madrid: Edelsa.

Gómez de Enterría, J. (2008). La enseñanza / aprendizaje de español con fines específicos. Madrid: Edinumen.

Radić Branisavljević, M., \& Milovanović, M. (2014). Savremene tehnologije u nastavi stranih jezika. Sinteza, pp. 500-505. Beograd: Univerzitet Singidunum. (In Serbian)

Sánchez Lobato, J., \& Santos Gargallo, I. (2004). Vademécum para la formación de profesores. Madrid: SGEL.

Special Eurobarometar. (n.d.). Retrieved May 30, 2014, from http://ec.europa.eu/public opinion/archives/ebs/ebs243en. pdf

Vučo, J., Ignjačević, A., \& Mirić, M. (2009). Jezik struke: Teorija i praksa. Beograd: Univerzitet u Beogradu. (In Serbian)

Warrschauer, M., \& Meskill, C. (2000). Technology and Second Language Teaching. Handbook of undergraduate second language education: 303-318. Retrieved February 10, 2014, from www.gse.uci.edu/person/warschauer $\mathrm{m} / \mathrm{tslt}$.html

White, K. (2013). Cultures and Communities in the Virtual World: Beginning the Exploration. Retrieved December 20, 2013, from www.iallt.org/sites/default/files/04 white cultures and communities iallt journ al 43-2pdf 